\title{
Література
}

1. Абдоков Ю. Б. Музыкальная поэтика хореографии: пластическая интерпретация музыки в хореографическом искусстве: дисс. ... канд. искусств.: 17.00.01 / Юрий Борисович Абдоков. - М., 2009. - 192 с. 2. Алпатов М. В. Этюды по всеобщей истории искусств / Михаил Владимирович Алпатов. - М. : Советский художник, 1979. - 287 с. З. Голейзовский К. Я. Жизнь и творчество: статьи, воспоминания, документы / К. Я. Голейзовский . - М. : Всероссийское театральное общество, 1984. - 576 с. 4. Лопухов Ф. В. Шестьдесят лет в балете / Федор Васильевич Лопухов. - М. : Искусство, 1966. - 424 с. 5. Лотман Ю. М. Лекции по структуральной поэтике / Юрий Михайлович Лотман. - М. : Гнозис, 1994. - 560 с. 6. Теория метафоры: [сб. статей] / ред. Арутюнова Н. Д., Журинская М. А. - М., 1990. $-512 \mathrm{c}$.

УДК:378:37.011.3-051:37.091.39

Наталія Волкова

\section{ЗМІСТОВО-ПРОЦЕСУАЛЬНИЙ ПІДХІД ЯК ОСНОВА РЕАЛІЗАЦІЇ ЕФЕКТИВНОГО ВЗАСМОЗВ'ЯЗКУ СТРУКТУРНИХ КОМПОНЕНТІВ НАВЧАННЯ У ПРОЦЕСІ ПІДГОТОВКИ МАЙБУТНЬОГО ВЧИТЕЛЯ ТЕХНОЛОГІї}

Волкова Н. В. Змістово-процесуальний підхід як основа реалізації ефективного взаємозв'язку структурних компонентів навчання у процесі підготовки майбутнього вчителя технології.

У статті розглядається питання про єдність змістового і процесуального аспектів навчання та зміст підготовки майбутнього вчителя трудового навчання. Обгрунтовано змістовні характеристики сучасного проекту як дидактичного засобу активізації пізнавальної діяльності із засвоєння змісту предметних знань, формування загальнонавчальних та спеціально-предметних умінь та навичок, розвитку креативності учнів.

Ключові слова: структурні компоненти, змістово-процесуальний підхід, якість освіти, майбутній учитель трудового навчання.

Волкова Н. В. Содержательно-процессуальный подход как основа реализации эффективной взаимосвязи структурных компонентов обучения в процессе подготовки будущего учителя технологии.

В статье поднимается вопрос о цельности содержательного и процесуального аспектов обучения и подготовка будущего учителя трудового обучения. Обоснованы содержательные характеристики современного проекта как дидактического средства активизации познавательной деятельности по усвоению содержания предметных знаний, формированию общеучебных и специально-предметных умений и навыков, развитию креативности учеников.

Ключевые слова: структурные компоненты, содержательно-процесуальный подход, качество образование.

Volkova N. V. Content and process approach as the basis to implement effective interconnection of structural components of training the future teacher of technology.

The article raises the question concerning the integrity of content and process aspects of educating and training future handicraft teachers. The author substantiates comprehensive characteristics of a modern project as a didactic means as for enhancing cognitive activity in 
the sphere of mastering the content of domain knowledge, forming common and specialized subject skills, developing students' creativity.

Key words: structural components, content and process approach, the quality of education.

Ускладнення функцій професійної праці передбачає подальше вдосконалення процесу навчання в загальноосвітній школі. Традиційне навчання, яке склалося у шкільній практиці, не може повною мірою ефективно виконати соціальне замовлення, потребуючи подальшого вдосконалення. Навчальний процес повинен надати кожному змогу зробити посильний, на основі своїх індивідуальних здібностей, знань, умінь, навичок, моральних і світоглядних пріоритетів, що визначають масштаб особистості, внесок у збагачення матеріальних і духовних цінностей світу.

Отже, орієнтація тільки на «знаннєвий» підхід, організацію предметного вивчення наукового знання не відповідає ані умовам, що змінилися, ані вимогам суспільства.

Сутність навчального процесу становить співдіяльність між педагогами й учнями, формування й розвиток в учнів мотивів і мотивації навчально-пізнавальної діяльності й навчання їх ефективної методики цієї діяльності. Тому основними ознаками навчального процесу повинні бути системність, цілісність, комплексність, планомірність, спрямованість на конкретний практичний результат, тривалість i організованість [7, с. 19]. На відміну від цього дидактичне поняття «процес навчання» охоплює тільки діяльність учителя й учня [7, с. 16].

Для того щоб з'ясувати сутність цих понять, необхідно розглянути, що становить ïх основу. Головними складниками понять «навчальний процес» $\mathrm{i}$ «процес навчання» є дидактичні поняття: «процес», «навчання», «діяльність».

Поняття «навчання» $є$ досить складною дидактичною категорією. Проаналізуємо кілька визначень, наявних у літературі. Так, у «Педагогічній енциклопедії» зазначається: «Навчання - це процес передавання й засвоєння знань, умінь, навичок i способів пізнавальної діяльності людини. Навчання - двосторонній процес, здійснюваний учителем (викладання) й учнями (учіння). У процесі навчання реалізуються цілі освіти».

На думку Н. Якси, «навчання - спеціально організований, цілеспрямований, керований процес взаємодії вчителів і учнів, спрямований на засвоєння знань, умінь i навичок, формування світогляду, розвиток розумових сил, творчих можливостей учнів. Навчання як процес містить дві органічно пов'язані діяльності (або підпроцеси), а саме: викладання - процес діяльності викладача (учителя) у процесі навчання, спрямований на організацію навчальної діяльності учнів, планомірне, систематичне передавання змісту освіти i формування необхідних якостей особистості; научіння - процес діяльності того, хто навчається (як під керівництвом, так і у процесі самоосвіти), спрямований на засвоєння змісту освіти й досвіду навчально-пізнавальної діяльності» [8, с. 126].

Б. Лихачов трактує навчання як суспільне явище, сутністю якого $\epsilon$ цілеспрямоване, організоване, систематичне передавання старшим та засвоєння підростаючим поколінням досвіду суспільних відносин, суспільної свідомості, культури виробничої праці, знань про активне перетворення та охорону навколишнього середовища; як процес становить цілеспрямовану, організовану за допомогою спеціальних методів і різноманітних форм активну навчальну взаємодію вчителів та учнів.

Отже, різні автори в центр уваги ставлять різноманітні боки навчання як 
процесу, проте всі одностайні в тому, що навчання - це спільна діяльність учителя й учнів. Діяльність учнів називають учінням, а діяльність учителя - викладанням, хоч іноді вживається інший термін, для більш точного відображення сутності діяльності вчителя - це научування [5, с. 38]). Навчання - це проста сума двох діяльностей, учіння і викладання, це ня органічна єдність.

Специфічні риси розглядуваного поняття по-різному виокремлюються в загальній педагогіці, дидактиці, методиках викладання, психології. Науковець В. Краєвський подає таку інтерпретацію: «На рівні педагогіки ми розглядаємо навчання як один із аспектів педагогічної діяльності й у цілому - діяльності 3 передачі суспільного досвіду підростаючим поколінням. На рівні дидактики навчання визначається як єдність викладання й учіння в діяльності щодо передавання змісту освіти. На рівні методики навчання - це сукупність форм реалізації діяльності викладання й учіння на матеріалі конкретного навчального предмета. На рівні психології навчання розглядається як сукупність взаємодій учителя й учня, у результаті яких відбувається збагачення інтелекту учнів, їхній психічний розвиток» [3, с. 52].

Під час розгляду змістового компонента навчання технологічного циклу дисциплін виходимо з його зумовленості змістом освіти. Вітчизняні теорії змісту освіти беруть початок у працях П. Блонського, П. Каптерева, К. Ушинського, які були розвинені у 80-ті роки минулого століття такими відомими дидактами, як-от: I. Журавльов, Л. Зоріна, В. Краєвський, I. Лернер, М. Скаткін та інші. Зокрема, глибоке науково-теоретичне обгрунтування теорія змісту освіти знаходить у працях I. Лернера, який виходить із концепції Л. Виготського про співвідношення навчання й розвитку: навчання $\epsilon$ необхідною умовою розвитку і навчання передує розвитку й детермінує його. Це означає, що розвитку без накопичення знань немає, як не може бути суто розвитку поза предметом навчання.

Meта статmi- розкрити змістово-процесуальний підхід у процесі підготовки майбутніх учителів трудового навчання.

Головна соціальна функція освіти - трансляція досвіду, накопиченого попередніми поколіннями людей. Досвід розглядається, з одного боку, як діяльність, утілена в знаннях, уміннях, творчості, а з іншого, - як ставлення до світу, тобто у формі матеріальної й духовної культури [2, с. 100].

Відтак, зміст освіти має передбачати:

1) систему знань про природу, суспільство, мислення, техніку, способи діяльності, засвоєння яких забезпечує формування у свідомості учнів правильної діалектико-матеріалістичної картини світу, озброює правильним методологічним підходом пізнавальної й практичної діяльності;

2) систему загальних інтелектуальних i практичних навичок, умінь, що $\epsilon$ основою сукупності конкретних діяльностей i таких, що забезпечують здатність молодого покоління до збереження культури суспільства;

3) досвід творчої діяльності, іiї основні риси, які поступово були накопичені людством у процесі розвитку суспільно-практичної діяльності, досвід, що забезпечує здатність до подальшого розвитку культури суспільства;

4) досвід емоційно-вольового ставлення до світу, один до одного, що є разом зі знаннями й уміннями умовою формування переконань i iдеалів, системи цінностей [2, с. 102].

Кожен із зазначених компонентів виконує свої визначені функції. Так, знання про світ і способи діяльності інтелектуального і практичного характеру слугують реалізації пізнавальної, орієнтаційної та оцінної функцій. Досвід здійснення способів 
діяльності виконує відтворювальну функцію, а досвід творчої діяльності перетворювальну. Досвід емоційно-ціннісного ставлення регулює вибіркове ставлення особистості до довкілля [4, с. 256-257]. Як бачимо, між компонентами змісту освіти існують зв'язки, оскільки кожен з попередніх $є$ умовою функціонування наступних, у сукупності - умовою формування цілісного світогляду особистості.

Під час відбору обсягу кожного конкретного компонента змісту освіти послуговуються кількома важливими положеннями, з-поміж них: природа і характер суспільства, необхідність підготовки до життя підростаючого покоління, яке активно працюватиме через 10-15 років, тенденції світового, культурного і наукового розвитку [5, с. 201].

Отже, на методологічному рівні зміст освіти визначають як педагогічну модель соціального замовлення, яке враховує запити школи. Проте зміст не копіює соціальне замовлення, а інтерпретує його засобами педагогічної науки через обсяг, логіку, темп засвоєння знань, можливі методи й засоби, реалізовані в певних організаційних формах [5, с. 191].

Виходячи з цього, джерелами змісту освіти є культура, види й галузі діяльності, логіка розгортання кожної з них, методи, засоби й організаційні форми навчання. 3-поміж чинників, що позначаються на змісті освіти, можна назвати потреби й цілі суспільства, закономірності навчання й учіння, середні й оптимальні можливості учнів, їхні особистісні потреби й інтереси.

У традиційній педагогіці, орієнтованої на реалізацію переважно освітніх функцій школи, зміст освіти визначається як сукупність систематизованих знань, умінь i навичок, поглядів і переконань, а також певний рівень розвитку пізнавальних сил і практичної підготовки, досягнуті в результаті навчально-виховної роботи. Це так званий знаннєво-орієнтований підхід до визначення сутності змісту освіти.

Науковцями В. Краєвським і І. Лернером обгрунтовано культурологічну модель змісту освіти, основою якої є чотирикомпонентний досвід особистості: знання про різні галузі дійсності, досвід виконання відомих способів діяльності, досвід творчої діяльності й досвід емоційно-ціннісного ставлення до об'єктів і засобів діяльності людини. Виходячи 3 діяльнісного підходу до структурування змісту освіти, в основу навчання вони пропонують покласти взаємодію викладання й учіння й у такий спосіб не зводити навчання до простого запам'ятовування й відтворення знань, а будувати його так, щоб знання становили засіб нагромадження досвіду учнів.

Цю ідею розвинено в роботах В. Давидова, Л. Занкова, Б. Ельконіна у межах теорії розвивального навчання. В. Давидовим обгрунтовано, що оволодіння учнями теоретичними поняттяи повинне слугувати інструментом побудови їх способів діяльності у предметній галузі [1]. Б. Ельконін пропонує відмовитися не від знань як наукової галузі, а від знань-відомостей, «знань про всяк випадок» [6, с. 27]. На перше місце він висуває не поінформованість того, кого навчають, а його вміння розв'язувати проблеми, що виникають у певних ситуаціях: 1) у пізнанні й поясненні явищ дійсності; 2) під час оволодіння сучасною технікою й технологією; 3) у взаєминах людей; 4) у практичному житті під час виконання соціальних ролей громадянина, члена родини, покупця, клієнта, глядача, виборця; 5) у правових нормах i адміністративних структурах, у споживчих і естетичних оцінках; 6) під час вибору професії й оцінки своєї готовності до навчання; 7) за необхідності розв’язувати власні проблеми 3 життєвого самовизначення, вибору стилю і способу життя, способу вирішення конфліктів. Згідно $з$ позицією Б. Ельконіна, зміст навчання повинен передбачати «ситуації включення»- необхідність проектування учнями дій, оцінку ситуації і ставлень, що сформувалися у процесі засвоєння. 
У педагогічній теорії знайшли визнання принципи формування змісту загальної освіти, розроблені В. Краєвським [3]. Насамперед це принцип відповідності змісту освіти у всіх його елементах і на всіх рівнях конструювання вимогам розвитку суспільства, науки, культури й особистості. Наступним є принцип структурної єдності змісту освіти на різних рівнях його формування і погодженість таких складників, як теоретичне подання, навчальний предмет, навчальний матеріал, педагогічна діяльність, особистість учня. 3-поміж головних вирізняється принцип єдності змістової і процесуальної сторін навчання, що нівелює його однобічну предметнонаукову орієнтацію. Він припускає урахування педагогічної реальності, пов'язаної зі здійсненням конкретного навчального процесу, поза яким не може бути реалізованим зміст освіти.

За предметною структурою зміст навчання є сукупністю змісту всіх навчальних предметів, які вивчаються у школі. При цьому навчальний предмет $є$ педагогічно адаптованою сукупністю знань і вмінь із якої-небудь окремої галузі дійсності і відповідної їй діяльності з засвоєння та застосування цих знань і вмінь у процесі навчальної взаємодії (І. Лернер). Отже, до змісту навчання, крім основ науки, входить зміст діяльності із засвоєння власне навчального матеріалу певної дисципліни, зміст діяльності з осмисленого сприймання навчальної і виховної діяльності учителя, діяльність спілкування всередині учнівського колективу [5]. На методичному рівні до змісту навчання Л. Панчешнікова включає знання (теорії, уявлення, факти), уміння i світоглядні ідеї.

Отже, взаємозв'язок між процесуальним і змістовим компонентами навчання стосується питання цілісності процесу навчання. Адже, якщо процесуальний бік відбиває динаміку навчання, навчання у його русі, зміні, а змістовий - містить у собі суто зміст у даному вигляді, у якому він може бути реалізованим у педагогічній діяльності, але жоден із цих складників не може бути функціональним один без одного.

У сучасному світі «знаннєва» освіта стає неприйнятною. Криза традиційної моделі навчання визначається тим, що старіння інформації відбувається значно швидше, ніж завершується природний процес навчання в середній школі. У зв'язку із цим установка на «передачу» від учителя до учнів «необхідного запасу знань» стає зовсім утопічною.

Нині в пошуках змісту освіти провідні науковці намагаються відійти від науково-предметної орієнтації. Зокрема, В. Ледньов і М. Коган в основу змісту освіти покладають діяльність людини, представлену практико-перетворювальним, пізнавальним, комунікативним, ціннісно-орієнтованим, естетичним ії видами.

Науковцями В. Краєвським і І. Лернером обгрунтовано культурологічну модель змісту освіти, основою якої є чотирикомпонентний досвід особистості: знання про різні галузі дійсності, досвід виконання відомих способів діяльності, досвід творчої діяльності й досвід емоційно-ціннісного ставлення до об'єктів і засобів діяльності людини. Виходячи $з$ діяльнісного підходу до структурування змісту освіти, в основу навчання вони пропонують покласти взаємодію викладання й учіння і в такий спосіб не зводити навчання до простого запам'ятовування й відтворення знань, а будувати його так, щоб знання були засобом нагромадження досвіду учнів.

Сучасний проект - це дидактичний засіб активізації пізнавальної діяльності із засвоєння змісту географічних знань, формування загальнонавчальних та спеціальнопредметних умінь та навичок, розвитку креативності учнів й одночасно становлення ïx певних особистісних якостей. Дидактичні можливості проектів, за дослідженнями С. Генкал, виходять 3 його сутнісних характеристик - цілеспрямо- 
ваності, елективності, ретельного планування кожного етапу та результату, динамічності, інтелектуального, евристичного, проблемного, творчого навантаження, варіативності та реалізації освітньої, наукової, пізнавально-розвивальної функції у процесі їх реалізації.

Зазначимо, що в педагогічному досвіді більшою мірою використовуються індивідуальні чи групові проекти в позаурочній діяльності чи поодинокі урокипроекти. Уважаємо за доцільне наголосити на умові широкого впровадження проектної діяльності у процес навчання технологічного циклу дисциплін. Це передбачає: проведення уроків-проектів; уроків-запуску проектів, на яких передбачено розроблення проблемних питань нової теми; уроки-презентації проектів; а також елементи проектної діяльності (міні-проекти) на уроках, що уможливлює співтворчість вчителя й учнів у вивченні нової теми; розвиток форм і методів реалізації проектної діяльності.

Розроблено чимало новітніх форм організації навчання, що передбачають проектну діяльність: урок-дослідження, урок-лабораторія, урок-творчий звіт, урок винахідництва, урок «дивовижне поруч», урок фантастичного проекту, урокрозповідь про науковців, урок-експертиза, урок-патент на відкриття, урок відкритих думок тощо.

Відтак, зміст навчання відтворюється в окремих проектах, а сприйняття, усвідомлення, осмислення й пізнання відбуваються у процесі їхньої реалізації. Це звісно змінює структуру процесу навчання і включає новий зміст і способи діяльності викладання й учіння, як-от: проектування, моделювання, конструювання, дослідження, презентацію індивідуального досвіду учня у засвоєнні технічного спрямування.

Переведення навчальної інформації в режим проектної діяльності забезпечує: 1) зміну цілей, завдань, мотивів діяльності учнів у засвоєнні змісту навчання, що стає практично значущим та орієнтованим на конкретний результат; 2) повноцінне засвоєння знань і способів їх здобуття в конкретній діяльності; 3) ускладнення процесуального компонента діяльності учнів; 4) перехід від діяльності за алгоритмом на творчу, перетворювальну; 5) перехід зовнішньої мотивації у внутрішню, а контроль 3 боку вчителя у самоконтроль 3 боку учня; 6) упровадження інтерактивних методів навчання, творчих i проблемних завдань, колективних i корпоративних форм, сучасних інформаційних технологій.

Отже, єдність змістового та процесуального аспектів навчання передбачає наявність у змісті всіх навчальних предметів пізнавальної і практичної перетворювальної діяльності. 3 іншого боку, всі форми, методи, засоби навчання, діяльність викладання й учіння реалізуються у процесі використання конкретного навчального матеріалу. Під час аналізу стану та процесу навчання технологічного циклу дисциплін почасти доволі важко чітко виокремити й розмежувати змістові і процесуальні його компоненти, що однак $\epsilon$ самостійними, водночас взаємозалежними складниками єдиного, цілісного процесу навчання. Тому питання про пошук доцільного взаємозв'язку між змістовим і процесуальними компонентами на різних етапах і ланках навчання $є$ достатньо актуальним, уможливлює розв'язання проблеми ефективності освіти.

\section{Література}

1. Давыдов В. В. Виды обобщения в обучении: логико-психологические проблемы построения учебных предметов/ Василий Васильевич Давыдов.- М. : Педагогическое общество России, 2000. - 480 с. 2. Дидактика средней школы: Некоторые проблемы современной дидактики: [учеб. пособие]/ ред. 
М. Н. Скаткина. - М. : Просвещение, 1982. - 319 с. З. Краевский В. В. Проблемы научного обоснования обучения (Методологический анализ) / Володар Викторович Краевский. - М. : Педагогика, 1977. - 264 с. 4. Лозова В. І. Теоретичні основи виховання і навчання: [навч. посібник] / В. І. Лозова, Г. В. Троцко. - Х. : ОВС, 2002. 400 с. 5. Малафіїк І. В. Дидактика: [навч. посібник] / Іван Васильович Малафіїк. - К. : Кондор, 2005. - 398 с. 6. Эльконин Б. Д. Понятие компетентности с позиций развивающего обучения / Б. Д. Эльконин // Современные подходы к компетентностно-ориентированному образованию : [материалы семинара]. - Самара : Профи, 2001. - С. 4-8. 7. Ягупов В. Дидактичні поняття: «навчальний процес» чи «процес навчання»? / Василь Ягупов// Рідна школа. - 2000. - № 2. - С. 16-19. 8. Якса Н. В. Основи педагогічних знань : [навч. посібн.] / Наталія Володимирівна Якса. - К. : Знання, 2007. - 358 с.

УДК 378.016:91

Олена Ганчук

\section{ОСОБЛИВОСТІ КЛАСИФІКАЦЇ̈ НАВЧАЛЬНИХ ЕКСКУРСІЙ 3 ГЕОГРАФІЇ, ЩО ВИКОРИСТОВУЮТЬСЯ У ПРОЦЕСІ ПІДГОТОВКИ МАЙБУТНІХ УЧИТЕЛІВ}

Ганчук О. В. Особливості класифікації навчальних екскурсій $з$ географії, що використовуються у процесі підготовки майбутніх учителів.

У статті розглянуто різні класифікації навчальних екскурсій. Подано авторську класифікацію навчальних екскурсій, де види екскурсій співвідносяться 3 формами групової пізнавальної діяльності студентів на кожному етапі їхнього професійного становлення.

Ключові слова: екскурсія, навчальна екскурсія, групова робота, пізнавальна діяльність.

Ганчук Е. В. Особенности классификации учебных экскурсий по географии, которые используются в процессе подготовки будущих учителей.

В статье рассмотрены различные классификации учебных экскурсий. Представлена авторская классификация учебных экскурсий, где виды экскурсий соотносятся с формами групповой познавательной деятельности студентов на каждом этапе их профессионального становления.

Ключевые слова: экскурсия, учебная экскурсия, групповая работа, познавательная деятельность.

Ganchuk O. V. Features of classification of educational excursions from geography, that is used in the process of preparation of future teachers.

The article deals with different classifications of educational excursions. The author gives her own classification of educational tours, where types of excursions correlate with forms of group cognitive activity of students at every stage of their professional development.

Key words: excursion, educational excursion, group work, cognitive activity.

Нині необхідна принципова перебудова і вдосконалення організації навчальновиховного процесу у вищих закладах освіти. Це насамперед стосується збільшення відсоткової частки тих форм навчання, які формують у студентів знання, уміння i навички, створюють умови для розвитку в них здатності самостійно добувати 